\title{
Tank 26F Supernatant and 2F Evaporator Eductor Pump Sample Characterization Results
}

\author{
William D. King \\ Michael S. Hay \\ Charles J. Coleman
}

August 2011

Savannah River National Laboratory Savannah River Nuclear Solutions, LLC Aiken, SC 29808

Prepared for the U.S. Department of Energy under contract number DE-AC09-08SR22470.

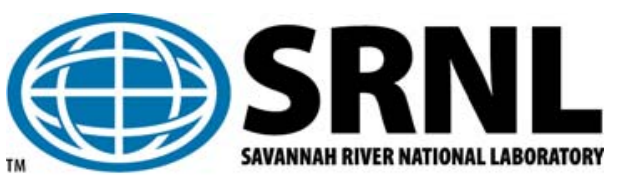


SRNL-STI-2011-00375

Revision 0

\section{DISCLAIMER}

This work was prepared under an agreement with and funded by the U.S. Government. Neither the U.S. Government or its employees, nor any of its contractors, subcontractors or their employees, makes any express or implied:

1. warranty or assumes any legal liability for the accuracy, completeness, or for the use or results of such use of any information, product, or process disclosed; or

2. representation that such use or results of such use would not infringe privately owned rights; or

3. endorsement or recommendation of any specifically identified commercial product, process, or service.

Any views and opinions of authors expressed in this work do not necessarily state or reflect those of the United States Government, or its contractors, or subcontractors.

\section{Printed in the United States of America \\ Prepared for \\ U.S. Department of Energy}


Keywords: Tank Waste, OLI

Thermodynamic Model

Retention: Permanent

\title{
Tank 26F Supernatant and 2F Evaporator Eductor Pump Sample Characterization Results
}

\author{
William D. King \\ Michael S. Hay \\ Charles J. Coleman
}

August 2011

Savannah River National Laboratory

Savannah River Nuclear Solutions, LLC Aiken, SC 29808

Prepared for the U.S. Department of Energy under contract number DE-AC09-08SR22470.

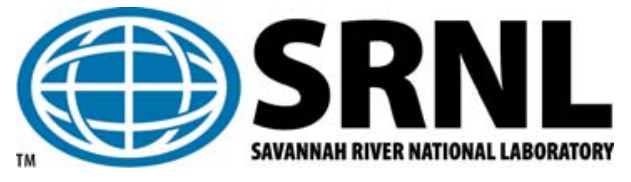




\section{REVIEWS AND APPROVALS}

AUTHORS:

W. D. King, SRNL/Advanced Characterization and Processing Date

\begin{tabular}{ll}
\hline M. S. Hay, SRNL/Advanced Characterization and Processing & Date
\end{tabular}

\begin{tabular}{ll}
\hline C. J. Coleman, SRNL/Analytical Development & Date
\end{tabular}

TECHNICAL REVIEW:

A. L. Washington, SRNL/Advanced Characterization and Processing Date

APPROVAL:

F. L. Pennebaker, Manager

Date

SRNL/Advanced Characterization and Processing

S. L. Marra, Manager

Date

Environmental \& Chemical Process Technology Research Programs

D. J. Martin, Manager

Date

SRR Tank Farm Engineering 
SRNL-STI-2011-00375

Revision 0

\section{EXECUTIVE SUMMARY}

In an effort to understand the reasons for system plugging problems in the SRS $2 \mathrm{~F}$ evaporator, supernatant samples were retrieved from the evaporator feed tank (Tank 26F) and solids were collected from the evaporator eductor feed pump for characterization. The variable depth supernatant samples were retrieved from Tank 26F in early December of 2010 and samples were provided to SRNL and the $\mathrm{F} / \mathrm{H}$ Area laboratories for analysis. Inspection and analysis of the samples at SRNL was initiated in early March of 2011. During the interim period, samples were frequently exposed to temperatures as low as $12{ }^{\circ} \mathrm{C}$ with daily temperature fluctuations as high as $10{ }^{\circ} \mathrm{C}$. The temperature at the time of sample collection from the waste tank was $51{ }^{\circ} \mathrm{C}$. Upon opening the supernatant bottles at SRNL, many brown solids were observed in both of the Tank $26 \mathrm{~F}$ supernatant samples. In contrast, no solids were observed in the supernatant samples sent to the $\mathrm{F} / \mathrm{H}$ Area laboratories, where the analysis was completed within a few days after receipt. Based on these results, it is believed that the original Tank 26F supernatant samples did not contain solids, but solids formed during the interim period while samples were stored at ambient temperature in the SRNL shielded cells without direct climate control.

Many insoluble solids ( $>11$ wt. \% for one sample) were observed in the Tank $26 \mathrm{~F}$ supernatant samples after three months of storage at SRNL which would not dissolve in the supernatant solution in two days at $51{ }^{\circ} \mathrm{C}$. Characterization of these solids along with the eductor pump solids revealed the presence of sodium oxalate and clarkeite (uranyl oxyhydroxide) as major crystalline phases. Sodium nitrate was the dominant crystalline phase present in the unwashed Eductor Pump solids. Crystalline sodium nitrate may have formed during the drying of the solids after filtration or may have been formed in the Tank 26F supernatant during storage since the solution was found to be very concentrated $\left(9-12 \mathrm{M} \mathrm{Na}^{+}\right)$. Concentrated mineral acids and elevated temperature were required to dissolve all of these solids. The refractory nature of some of the solids is consistent with the presence of metal oxides such as aluminosilicates (observed as a minor phase by XRD). Characterization of the water wash solutions and the digested solids confirmed the presence of oxalate salts in both solid samples. Sulfate enrichment was also observed in the Tank $26 \mathrm{~F}$ solids wash solution, indicating the presence of sulfate precipitates such as burkeite.

OLI modeling of the Tank 26F filtered supernatant composition revealed that sodium oxalate has a very low solubility in this solution. The model predicts that the sodium oxalate solubility in the Tank $26 \mathrm{~F}$ supernatant is only $0.0011 \mathrm{M}$ at $50{ }^{\circ} \mathrm{C}$. The results indicate that the highly concentrated nature of the evaporator feed solution and the addition of oxalate anion to the waste stream each contribute to the formation of insoluble solids in the $2 \mathrm{~F}$ evaporator system. 


\section{TABLE OF CONTENTS}

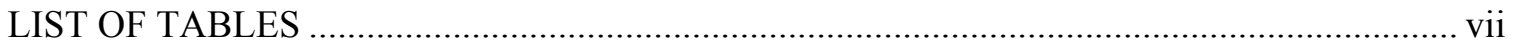

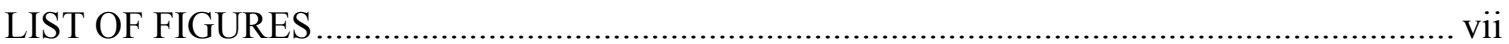

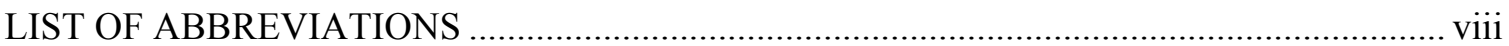

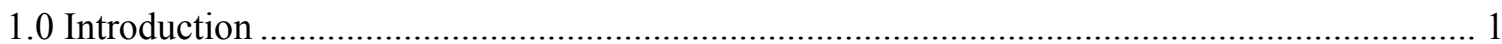

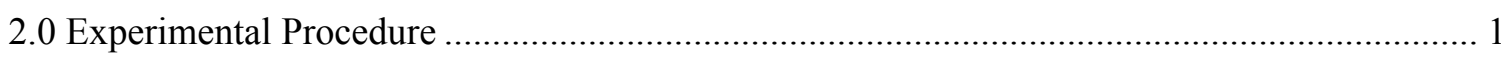

2.1 Weight Percent Solids and Density Measurements .................................

2.2 Sample Handling and Chemical and Crystallographic Analysis......................

2.3 Thermodynamic Modeling......................................................

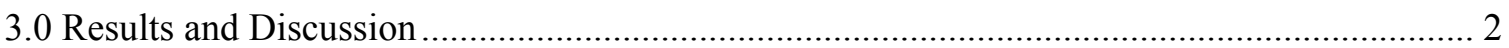

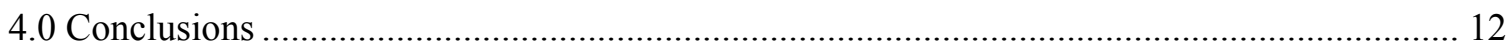

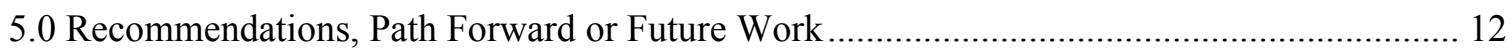

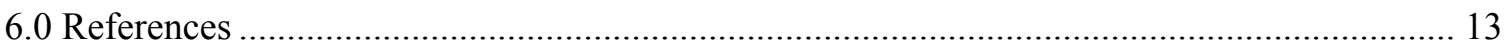




\section{LIST OF TABLES}

Table 3-1 Tank 26F Sample FTF-26-10-57 Density and Weight Percent Solids Data ................. 6

Table 3-2 Water Wash Characterization Data for the Tank 26F Sample FTF-26-10-57 and Eductor Pump Solids ............................................................6

Table 3-3 Digested Insoluble Solids Characterization Data for the Water-Washed Tank 26F and

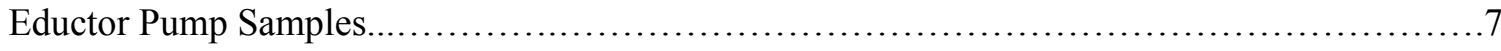

Table 3-4 Tank 26F Sample FTF-26-10-57 Filtered Supernatant Characterization .............. 8

Table 3-5 F/H Area Lab Results for Tank 26F Supernatant Samples ..........................

\section{LIST OF FIGURES}

Figure 3-1. XRD analysis results for unwashed solids isolated from Tank 26F Sample

Figure 3-2. XRD analysis results for unwashed Eductor Pump solids 10

Figure 3-3. XRD analysis results for water-washed solids isolated from Tank 26F Sample FTF-26-10-57. . .11

Figure 3-4. XRD analysis results for water-washed Eductor Pump solids. .11 


\section{LIST OF ABBREVIATIONS}

$\begin{array}{ll}\text { ADS } & \text { Analytical Development Section } \\ \text { ESP } & \text { Environmental Simulation Program } \\ \text { IC anion } & \text { Ion Chromatography Anion } \\ \text { ICP-ES } & \text { Inductively Couple Plasma Emission Spectroscopy } \\ \text { NA } & \text { Not Available } \\ \text { SRNL } & \text { Savannah River National Laboratory } \\ \text { TTR } & \text { Technical Task Request } \\ \text { TTQAP } & \text { Technical Task and Quality Assurance Plan } \\ \text { WCS } & \text { Waste Characterization System } \\ \text { XRD } & \text { X-ray Diffraction }\end{array}$




\subsection{Introduction}

In December of 2010, samples were collected from the $2 \mathrm{~F}$ evaporator system in two locations. Duplicate $200 \mathrm{~mL}$ variable depth supernatant (VDS) samples were collected from pump suction height (161" above floor level) within the evaporator feed tank, Tank 26F. Identification numbers for these samples were FTF-26-10-57 and FTF-26-10-58. In addition, a sample of solid material was isolated from the $2 \mathrm{~F}$ evaporator eductor feed pump. These three samples were provided to the Savannah River National Laboratory (SRNL) for analysis. Separate Tank 26F supernatant samples collected at the same time were also provided to the Savannah River Site $\mathrm{F} / \mathrm{H}$ Area laboratories for analysis. Characterization of these samples was conducted in an effort to determine the cause of frequent $2 \mathrm{~F}$ Evaporator problems during the past year associated with solids formation in the system which resulted in the plugging of system components such as pumps and pipes and led to processing interruptions.

\subsection{Experimental Procedure and Modeling Approach}

This work was conducted following the associated Technical Task Request (TTR) ${ }^{1}$ and Technical Task and Quality Assurance Plan (TTQAP) ${ }^{2}$ for this task.

\subsection{Weight Percent Solids and Density Measurements}

Weight percent solids measurements were conducted by drying samples in a drying oven at 112 ${ }^{\circ} \mathrm{C}$ until no additional weight loss was observed. The weight percent of dissolved solids is defined as the weight of dissolved solids divided by the weight of initial filtered supernatant (x100). For these measurements, the supernatant was filtered using a $0.45 \mu \mathrm{m}$ Nylon filter. The weight percent of total solids is defined as the weight of total solids (dissolved and insoluble)

divided by the weight of initial slurry (x100). Weight percent dissolved and total solids measurements were conducted in triplicate. The weight percent of insoluble solids is defined as the weight of insoluble solids divided by the weight of initial slurry (x100). This value was calculated from the measured values for weight percent total and dissolved solids using the formula below.

Wt. $\%_{\text {insoluble }}=\left(\right.$ Wt. $\%_{\text {total }}-$ Wt. $\left.\%_{\text {dissolved }}\right) /\left(100-\right.$ Wt. $\left.\%_{\text {dissolved }}\right)$

The weight percent of soluble solids is defined as the weight of dissolved solids divided by the weight of initial slurry (x100). This value was calculated by subtracting the weight percent of insoluble solids from the weight percent of total solids.

Density measurements were conducted at ambient cell temperature in triplicate using $8.5 \mathrm{~mL}$ tubes fabricated and calibrated in the shielded cells.

\subsection{Sample Handling and Chemical and Crystallographic Analysis}

Analyses of water washes and digested solids were conducted on single samples. Samples of the Tank 26F solids and the Eductor Pump solids were isolated by filtration through $0.45 \mu \mathrm{m}$ Nylon filters. Small sub-samples of the unwashed solids were collected for XRD analysis using a spatula. The remaining filter cake solids were then washed with $10 \mathrm{~mL}$ portions of deionized water using a five minute soak time. $2 \mathrm{~mL}$ portions of the initial wash solutions were diluted into 
$248 \mathrm{~mL}$ of deionized water prior to removal from the cells for analysis. The solid samples remaining on the filter cups were subsequently washed in the same manner with three additional $10 \mathrm{~mL}$ portions of water. Small sub-samples of the washed solids were then collected for XRD analysis using a spatula. Acid digestion of the remaining solids on the filter cups was conducted following standard procedures using combinations of concentrated nitric, sulfuric, and hydrofluoric acids. Samples were heated to $115^{\circ} \mathrm{C}$ in Teflon bombs overnight to promote complete solids dissolution. The nitrate, chloride, and fluoride concentrations in the final acid digestion solutions were $0.11-0.15 \mathrm{M}, 0.11-0.17 \mathrm{M}$, and 0.07-0.1 $\mathrm{M}$, respectively. The anion concentrations are believed to primarily reflect the amounts of the various acids added for dissolution rather than salts dissolved from the sample. Duplicate sub-samples of the filtered (0.45 $\mu \mathrm{m}$ Nylon) supernatant were also analyzed following dilution in $3 \mathrm{M}$ nitric acid (ICP-ES analysis) or water (IC anion analysis).

\subsection{Thermodynamic Modeling}

A thermodynamic model was developed using the OLI Systems Inc, Environmental Simulation Program (ESP), version 8.3 to evaluate the stability of the Tank $26 \mathrm{~F}$ feed solution towards precipitation. The model was composed of a single Mix block allowing for the evaluation of the solution stability at two temperatures. The chemistry model for the simulations included the GEOCHEM database as the source for the inclusion of aluminosilicate compounds in the model.

\subsection{Results and Discussion}

Inspection and analysis of the samples at SRNL was initiated in March of 2011. Upon opening the supernatant bottles, many brown solids were observed in both Tank $26 \mathrm{~F}$ supernatant samples. Sample FTF-26-10-57 contained approximately 50\% solids by volume, while Sample FTF-26-1057 contained $10-20 \%$ solids by volume, based on visual observations. In contrast, no solids were reported in the Tank 26F supernatant samples analyzed earlier in the $\mathrm{F} / \mathrm{H}$ area laboratories. Sample FTF-26-10-57 was heated at SRNL to the tank temperature recorded during sample collection $\left(51^{\circ} \mathrm{C}\right)$ in a drying oven in a sealed bottle for over two days. No decrease in the volume percent of solids was observed after heating, based on visual inspection. The Eductor Pump solids were brown in appearance and contained little free liquid. Initial masses of the samples received at SRNL were: $272.58 \mathrm{~g}$ of FTF-26-10-57 slurry, $256.59 \mathrm{~g}$ of FTF-26-10-58 slurry, and $9.66 \mathrm{~g}$ of Eductor Pump solids. Subsequent characterization efforts focused on the Eductor Pump solids and the Sample FTF-26-10-57 slurry which had been heated in the oven.

Weight percent solids and density data for Tank 26F Sample FTF-26-10-57 are provided in Table 3-1. The sample contained $11 \mathrm{wt} . \%$ insoluble solids. The weight percent soluble solids value observed for this sample of approximately $40 \%$ indicated that the supernatant was concentrated. Weight percent soluble solids values for pure sodium hydroxide and sodium nitrate solutions of $40 \%$ correspond to concentrations near 14 and $6 \mathrm{M}$, respectively, so it was expected that the Tank $26 \mathrm{~F}$ supernatant was in this concentration range. The measured slurry and filtered $(0.45 \mu \mathrm{m}$ Nylon filter) supernatant densities of $>1.4 \mathrm{~g} / \mathrm{mL}$ are also consistent with a concentrated solution.

The Tank 26F Sample FTF-26-10-57 slurry and the Eductor Pump sample were transferred to separate $0.45 \mu \mathrm{m}$ Nylon filter units and the free liquid was removed under vacuum. Small subsamples of the unwashed solids were then removed for XRD analysis. XRD results for the unwashed Tank 26F solids and Eductor Pump solids are provided in Figures 3-1 and 3-2, respectively. The dominant crystalline phases present in the unwashed Tank 26F solids were 
natroxalate, $\mathrm{Na}_{2}\left(\mathrm{C}_{2} \mathrm{O}_{4}\right)$, and clarkeite, $\mathrm{Na}\left(\mathrm{UO}_{2}\right)(\mathrm{O}) \mathrm{OH} \cdot \mathrm{H}_{2} \mathrm{O}$. Trace amounts of nitratine, $\mathrm{NaNO}_{3}$, were present which may have formed when the sample dried on the filter cup. The dominant crystalline phase in the unwashed Eductor Pump solids was nitratine. This crystalline phase could also have formed during evaporation of the residual supernatant on the filter. However, the fact that nitratine was such a dominant phase in the XRD scan may be an indication that sodium nitrate solids were present in the original Eductor Pump solids. The minor peaks indicate the presence of low levels of sodium oxalate and carbonate solids in the Eductor Pump sample.

The filter cake from the Tank 26F and the Eductor Pump solids were subsequently washed with separate portions of deionized water. There was little visual indication of solids dissolution for either sample. The initial wash filtrate solutions were submitted for analysis and the results are provided in Table 3-2. The primary chemical constituents for both wash samples included sodium, aluminum, and various anions including oxalate. Most of the sodium and aluminum salts in the wash solutions are believed to result from residual salt solution remaining on the solids after filtration. The Tank $26 \mathrm{~F}$ solids wash solution was more concentrated than the Eductor Pump solids wash solution and the Tank 26F sample wash solution contained significant sulfur, indicating the presence of a sulfate phase like burkeite $\left(\mathrm{Na}_{6}\left(\mathrm{SO}_{4}\right)_{2}\left(\mathrm{CO}_{3}\right)\right)$. The carbonate detection limit for this sample is too high to confirm the presence of burkeite in the sample. Hydroxide (not analyzed) likely accounts for the remaining $40-60 \%$ of the anions required for charge balance in these solutions.

The remaining filter cake for each solid sample was subsequently washed in the same manner with three additional $10 \mathrm{~mL}$ portions of deionized water. These wash fractions were not analyzed. Sub-samples of the washed solids were submitted for XRD analysis and the results are provided in Figures 3-3 and 3-4. The water-washed Tank 26F sample solids contained natroxalate and clarkeite, as was the case for the unwashed sample. However, peaks associated with natroxalate in the XRD of the washed Tank 26F sample were present at significantly lower levels than observed in the unwashed sample relative to other phases, indicating that some sodium oxalate had dissolved during washing. Other minor phases identified in the Tank 26F solids included hematite, iron oxalate mono-hydrate, and sodium aluminosilicate. XRD results for the waterwashed Eductor Pump solids included clarkeite and natroxalate as primary phases with some indication of aluminosilicate crystalline phases. Based on this result, it appears that washing was not as effective at removing the sodium oxalate from the Eductor Pump solids, but was effective at dissolving the sodium nitrate salts present as nitratine. In summary, natroxalate was observed in all four of the XRD scans obtained (washed and unwashed) for the Tank 26F and the Eductor Pump solids, while clarkeite was observed in three of four scans.

Portions of the washed solids on each filter were dissolved in concentrated mineral acids. Only partial solids dissolution was observed with the addition of nitric and hydrochloric acids prior to the addition of HF and heat. This observation is consistent with the presence of more refractory phases such as aluminosilicates. Two portions of the Eductor Pump solids were submitted separately for analysis due to the observation of some large agglomerates on the filter that appeared lighter in color. Several larger agglomerates were carefully collected from the filter cake and digested separately from the bulk sample. Analysis results for the Tank 26F, Bulk Eductor Pump, and Eductor Pump Agglomerate solids after acid digestion are provided in Table 3-3. On a mass basis, iron and uranium were the dominant metals observed in the Tank $26 \mathrm{~F}$ solids, while sodium was the dominant metal observed in the Eductor Pump solids. On a molar basis, the Tank $26 \mathrm{~F}$ solids contained $92 \%$ as much iron and $22 \%$ as much uranium as sodium, while the Eductor Pump solids contained no more than $11 \%$ of any metal relative to sodium. The Tank 26F solids also contained significant amounts of aluminum, calcium, and silicon $(20-30 \%$ on a molar basis for each metal relative to $\mathrm{Na}$ ). High fluoride, chloride, and nitrate levels were 
observed in the IC anion results (not shown) for all three types of digested solids as a result of the acid mixtures used for dissolution. Oxalate anion accounts for 15-21 weight percent of the Eductor Pump samples but $<0.5$ weight percent of the Tank $26 \mathrm{~F}$ solids. This is consistent with observations from the XRD analysis which indicated that sodium oxalate levels decreased in the Tank $26 \mathrm{~F}$ solids after washing. These results indicate that the educator pump solids were composed of 24-32 percent sodium oxalate $\left(\mathrm{Na}_{2} \mathrm{C}_{2} \mathrm{O}_{4}\right)$ on a mass basis.

A sample of the Tank 26F supernatant was isolated by filtration through a $0.45 \mu \mathrm{m}$ filter and two sub-samples were submitted for analysis. The results are provided in Table 3-4. As expected based on the measured density in Table 3-1, the supernatant was concentrated. The average measured sodium concentration was $11.6 \mathrm{M}$ and the average aluminum concentration was $0.64 \mathrm{M}$. The average nitrite and nitrate concentrations determined by IC anion were each near $1.9 \mathrm{M}$. No measurable oxalate anion was observed in either sample at concentrations $\geq 0.021 \mathrm{M}$. The average free hydroxide was $4.4 \mathrm{M}$ and the average total inorganic carbon (expected to be primarily carbonate) was $0.11 \mathrm{M} \mathrm{C}$ (or carbonate). The average sulfate concentration in the filtered supernatant of $<0.02 \mathrm{M}$ confirms that the Tank $26 \mathrm{~F}$ wash solutions were significantly enriched in sulfate relative to sodium, indicating that these solids contained a sulfate phase. The anion and cation molar concentrations for the supernatant analysis do not balance. The sum of the anion concentrations would be consistent with a total sodium concentration near $9 \mathrm{M}$. Since sodium analysis at these concentrations can be challenging, it is suspected that the measured sodium concentration might be in error. The characterization data reported for the original supernatant received in the $\mathrm{F} / \mathrm{H}$ area laboratories is summarized in Table 3-5. Detailed comparison of the SRNL analysis results on the Tank $26 \mathrm{~F}$ filtered supernate to the $\mathrm{F} / \mathrm{H}$ area laboratories results for the unfiltered supernatant material yields the following observations. The SRNL analysis results were 55\% higher in both sodium and aluminum and $41 \%$ higher in hydroxide. The SRNL analysis results were 30\% lower in nitrate, $54 \%$ lower in carbonate, and at least $72 \%$ lower in sulfate. These compositional differences are consistent with the formation of several of the solid phases believed to have precipitated from solution in the SRNL sample.

The average Tank 26F filtered supernatant composition shown in Table 3-4 was used as the input stream to the OLI Thermodynamic model with a sodium concentration of $9.14 \mathrm{M}$ matching the sum of the major anion concentrations. This sodium concentration is somewhat lower than the $11.57 \mathrm{M}$ sodium concentration measured, but the software requires balanced cations and anions. The Al, P, and S concentrations from the ICP-ES analysis were used for the concentrations of sodium aluminate, sodium phosphate, and sodium sulfate in the supernatant. The model predicts that the solution composition provided in Table 3-4 is stable to precipitation but is very sensitive to the oxalate concentration. An oxalate anion concentration of $>0.0005 \mathrm{M}$ promotes precipitation of sodium oxalate at $25{ }^{\circ} \mathrm{C}$ or less. At $50{ }^{\circ} \mathrm{C}$, the oxalate solubility increases to $\sim 0.0011 \mathrm{M}$. The high sensitivity to oxalate predicted by the model for the Tank $26 \mathrm{~F}$ supernatant aligns with the composition of the solids found in the samples which indicated that sodium oxalate was a major constituent. The other major anions were also evaluated to determine the sensitivity of the solution to changes in concentration or temperature. For aluminum hydroxide, an increase in the concentration from $\sim 0.6 \mathrm{M}$ to $\sim 0.9 \mathrm{M}$ will result in precipitation of sodium aluminate if the temperature decreases to $10{ }^{\circ} \mathrm{C}$. At a solution temperature of $25{ }^{\circ} \mathrm{C}$ the aluminum hydroxide concentration would need to increase to $\sim 1.6 \mathrm{M}$ before precipitation will occur (highest measured Al: $0.64 \mathrm{M}$ ). For both nitrate and nitrite anions, precipitation of these sodium salts can occur if the solution concentration of either anion rises to $\sim 2.5 \mathrm{M}$ at $10{ }^{\circ} \mathrm{C}$, but would need to reach $\sim 3.4 \mathrm{M}$ at $25{ }^{\circ} \mathrm{C}$ before precipitation would occur. The $\mathrm{F} / \mathrm{H}$ area laboratory result for nitrate for one sample was $2.6 \mathrm{M}$. The carbonate concentration would need to increase to $\sim 0.4 \mathrm{M}$ (highest measured $\mathrm{CO}_{3}{ }^{2-}: 0.26 \mathrm{M}$ ) and the temperature rise to $50{ }^{\circ} \mathrm{C}$ before any precipitation occurs. In this case, Burkeite $\left(\mathrm{Na}_{6}\left(\mathrm{CO}_{3}\right)\left(\mathrm{SO}_{4}\right)_{2}\right)$, a double salt of sodium sulfate and 
sodium carbonate, is predicted to precipitate. According to the model, Burkeite only crystallizes from solution at temperatures over $30{ }^{\circ} \mathrm{C}$ and, like sodium carbonate and sodium sulfate, exhibits decreasing solubility with increasing temperature. Likewise, the sulfate concentration would need to increase to $\sim 0.059 \mathrm{M}$ at a temperature of $50{ }^{\circ} \mathrm{C}$ before any Burkeite precipitation occurred. The Tank 26F supernatant compositions from WCS shown in Table 3-5 were also modeled and showed similar sensitivity to oxalate concentrations.

Dilution of the solution composition in Table 3-4 to a sodium concentration of $4.85 \mathrm{M}$ increases the solubility of sodium oxalate from $\sim 0.0005 \mathrm{M}$ in the concentrated solution to $\sim 0.004 \mathrm{M}$ in the diluted solution at $25{ }^{\circ} \mathrm{C}(\sim 8 \mathrm{X}$ increase). The model also predicts that the oxalate solubility increases to $0.009 \mathrm{M}$ upon dilution at $50{ }^{\circ} \mathrm{C}$. In addition, dilution promotes the precipitation of a small amount of $\mathrm{Al}(\mathrm{OH})_{3}$, according to the model. It therefore appears that dilution does not enhance sodium oxalate solubility in the supernate sufficiently to prevent precipitation of solids in the evaporator system. 
Table 3-1 Tank 26F Sample FTF-26-10-57 Density and Weight Percent Solids Data

\begin{tabular}{|c|c|c|c|c|c|}
\hline $\begin{array}{c}\text { Wt. \% } \\
\text { Total } \\
\text { Solids }\end{array}$ & $\begin{array}{c}\text { Wt. \% } \\
\text { Dissolved } \\
\text { Solids }\end{array}$ & $\begin{array}{c}\text { Wt. \% } \\
\text { Insoluble } \\
\text { Solids }^{\mathbf{b}}\end{array}$ & $\begin{array}{c}\text { Wt. \% } \\
\text { Soluble } \\
\text { Solids }\end{array}$ & $\begin{array}{c}\text { Slurry } \\
\text { Density } \\
(\mathbf{g} / \mathbf{m L})^{\mathbf{c}}\end{array}$ & $\begin{array}{c}\text { Supernatant } \\
\text { Density } \\
(\mathbf{g} / \mathbf{m L})^{\mathbf{c}}\end{array}$ \\
\hline $52.2(0.7)$ & $46.0(0.4)$ & 11.4 & 40.7 & $1.50(0.5)$ & $1.42(0.3)$ \\
\hline
\end{tabular}

${ }^{\mathrm{a}}$ Values in parenthesis indicate the percent relative standard deviation.

${ }^{b}$ The weight percent soluble and insoluble solids values were calculated from the weight percent total and dissolved solids measurements.

${ }^{\mathrm{c}}$ Density measurements were conducted at $28^{\circ} \mathrm{C}$ in the SRNL Shielded Cells.

Table 3-2 Water Wash Characterization Data for the Tank 26F Sample FTF-26-10-57 and Eductor Pump Solids

\begin{tabular}{|c|c|c||}
\hline \hline & FTF-26-10-57 & Eductor Pump \\
\hline & $\mathrm{M}$ & $\mathrm{M}$ \\
\hline $\mathrm{Al}$ & 0.101 & 0.026 \\
\hline $\mathrm{Ca}$ & $1.87 \mathrm{E}-05$ & $4.43 \mathrm{E}-05$ \\
\hline $\mathrm{Cr}$ & $7.24 \mathrm{E}-04$ & $2.43 \mathrm{E}-04$ \\
\hline $\mathrm{Fe}$ & $5.06 \mathrm{E}-05$ & $<2.24 \mathrm{E}-05$ \\
\hline $\mathrm{K}$ & $8.18 \mathrm{E}-03$ & $<1.28 \mathrm{E}-03$ \\
\hline $\mathrm{Na}$ & 3.795 & 0.707 \\
\hline $\mathrm{P}$ & $6.86 \mathrm{E}-03$ & $9.28 \mathrm{E}-04$ \\
\hline $\mathrm{S}$ & 0.230 & $<0.006$ \\
\hline Nitrate & 0.935 & 0.153 \\
\hline Nitrite & 0.334 & 0.082 \\
\hline Sulfate & 0.207 & $<0.007$ \\
\hline Oxalate & 0.036 & 0.078 \\
\hline Fluoride & 0.059 & $<0.007$ \\
\hline \multicolumn{2}{|l}{} \\
\hline Carbon & $\mathrm{mg} / \mathrm{L}$ & $\mathrm{mg} / \mathrm{L}$ \\
\hline Inorganic & $<1.58 \mathrm{E}+04$ & $<1.58 \mathrm{E}+04$ \\
\hline Organic & $<7.88 \mathrm{E}+03$ & $<7.88 \mathrm{E}+03$ \\
\hline Total & $<7.88 \mathrm{E}+03$ & $<7.88 \mathrm{E}+03$ \\
\hline \hline
\end{tabular}


Table 3-3 Digested Insoluble Solids Characterization Data for the Water-Washed Tank 26F (FTF-26-10-57) and Eductor Pump Samples

\begin{tabular}{|c|c|c|c|}
\hline & "FTF-26-10-57 & $\begin{array}{l}\text { Eductor Pump } \\
\text { Bulk Solids }\end{array}$ & $\begin{array}{c}\text { Eductor Pump } \\
\text { Large Agglomerates }\end{array}$ \\
\hline & Wt. $\%^{a}$ & Wt. $\%^{a}$ & Wt. $\%^{a}$ \\
\hline $\mathrm{Al}$ & 0.89 & 0.34 & 0.10 \\
\hline $\mathrm{B}$ & 0.02 & 0.01 & $<0.01$ \\
\hline $\mathrm{Ba}$ & 0.06 & 0.04 & 0.01 \\
\hline $\mathrm{Ca}$ & 1.22 & 0.25 & 0.07 \\
\hline $\mathrm{Co}$ & $<0.01$ & 0.01 & $<0.01$ \\
\hline $\mathrm{Cr}$ & 1.09 & 0.89 & 0.51 \\
\hline $\mathrm{Cu}$ & $<0.01$ & 0.01 & $<0.01$ \\
\hline $\mathrm{Fe}$ & 7.01 & 4.87 & 2.41 \\
\hline $\mathrm{La}$ & 0.01 & 0.004 & 0.01 \\
\hline $\mathrm{Mg}$ & 0.35 & 0.07 & 0.02 \\
\hline $\mathrm{Mn}$ & 0.40 & 0.30 & 0.09 \\
\hline $\mathrm{Na}$ & 3.15 & 18.50 & 27.30 \\
\hline $\mathrm{Ni}$ & 0.19 & 0.53 & 0.30 \\
\hline $\mathrm{Si}$ & 1.10 & 0.78 & 0.96 \\
\hline $\mathrm{Sr}$ & 0.01 & 0.003 & 0.001 \\
\hline $\mathrm{Ti}$ & 0.02 & 0.01 & 0.003 \\
\hline $\mathrm{U}$ & 7.16 & 1.53 & $<0.71$ \\
\hline $\mathrm{Zn}$ & 0.01 & 0.01 & 0.004 \\
\hline $\mathrm{Zr}$ & 0.02 & 0.004 & $<0.004$ \\
\hline Nitrite & $<0.5$ & $<0.4$ & $<0.8$ \\
\hline Phosphate & $<0.5$ & $<0.4$ & $<0.8$ \\
\hline Sulfate & $<0.5$ & $<0.4$ & $<0.8$ \\
\hline Oxalate & $<0.5$ & 15.7 & 20.8 \\
\hline
\end{tabular}

${ }^{\mathrm{a}}$ weight percent based on initial weight of damp washed solids 
SRNL-STI-2011-00375

Revision 0

Table 3-4 Tank 26F Sample FTF-26-10-57 Filtered Supernatant Characterization

\begin{tabular}{|c|c|c|c||}
\hline & Sub-sample A & Sub-sample B & Average \\
\hline & M & M & M \\
\hline $\mathrm{Al}$ & 0.644 & 0.639 & 0.641 \\
\hline $\mathrm{B}$ & $2.36 \mathrm{E}-02$ & $2.34 \mathrm{E}-02$ & $2.35 \mathrm{E}-02$ \\
\hline $\mathrm{Ca}$ & $6.46 \mathrm{E}-05$ & $1.08 \mathrm{E}-04$ & $8.64 \mathrm{E}-05$ \\
\hline $\mathrm{Cr}$ & $2.73 \mathrm{E}-03$ & $2.72 \mathrm{E}-03$ & $2.72 \mathrm{E}-03$ \\
\hline $\mathrm{Fe}$ & $2.54 \mathrm{E}-04$ & $4.68 \mathrm{E}-04$ & $3.61 \mathrm{E}-04$ \\
\hline $\mathrm{K}$ & $7.29 \mathrm{E}-02$ & $7.30 \mathrm{E}-02$ & $7.30 \mathrm{E}-02$ \\
\hline $\mathrm{Mn}$ & $7.88 \mathrm{E}-05$ & $7.74 \mathrm{E}-05$ & $7.81 \mathrm{E}-05$ \\
\hline Mo & $8.89 \mathrm{E}-04$ & $8.93 \mathrm{E}-04$ & $8.91 \mathrm{E}-04$ \\
\hline Na & 11.520 & 11.628 & 11.574 \\
\hline$P$ & $1.20 \mathrm{E}-02$ & $1.23 \mathrm{E}-02$ & $1.22 \mathrm{E}-02$ \\
\hline S & $2.16 \mathrm{E}-02$ & $2.23 \mathrm{E}-02$ & $2.20 \mathrm{E}-02$ \\
\hline Fluoride & $<0.097$ & $<0.095$ & $<0.096$ \\
\hline Chloride & $<0.052$ & $<0.051$ & $<0.051$ \\
\hline Nitrite & 1.995 & 1.900 & 1.947 \\
\hline Nitrate & 1.888 & 1.809 & 1.849 \\
\hline Sulfate & $<0.019$ & $<0.019$ & $<0.019$ \\
\hline Oxalate & $<0.021$ & $<0.021$ & $<0.021$ \\
\hline Total Base & 6.94 & 6.79 & 6.86 \\
\hline Free OH & 4.59 & 4.22 & 4.40 \\
\hline Other Base & 0.86 & 0.87 & 0.87 \\
\hline & & & \\
\hline Carbon & $u g \mathrm{C} / \mathrm{mL}$ & $u g \mathrm{C} / \mathrm{mL}$ & ug C/mL \\
\hline Total Carbon & $<1.85 \mathrm{E}+03$ & $<1.81 \mathrm{E}+03$ & $<1.83 \mathrm{E}+03$ \\
\hline Inorganic Carbon & $1.28 \mathrm{E}+03$ & $1.25 \mathrm{E}+03$ & $1.27 \mathrm{E}+03$ \\
\hline Organic Carbon & $<5.69 \mathrm{E}+02$ & $<5.61 \mathrm{E}+02$ & $<5.65 \mathrm{E}+02$ \\
\hline \hline
\end{tabular}


Table 3-5 F/H Area Lab Results for Tank 26F Supernatant Samples Collected on 12/2/2010 (results reported in WCS)

\begin{tabular}{|l|c|c|}
\hline Sample & 200557216 & 200557237 \\
\hline & $\mathrm{M}$ & $\mathrm{M}$ \\
\hline $\mathrm{Na}$ & 6.84 & 8.14 \\
\hline $\mathrm{Al}$ & 0.399 & 0.429 \\
\hline $\mathrm{Si}$ & 0.0006 & 0.0006 \\
\hline Nitrate & 2.59 & $\mathrm{NA}$ \\
\hline Nitrite & 1.31 & $\mathrm{NA}$ \\
\hline Sulfate & 0.066 & 0.072 \\
\hline Phosphate & 0.011 & 0.012 \\
\hline Oxalate & $<0.0056$ & 0.0028 \\
\hline Carbonate & 0.223 & 0.259 \\
\hline Hydroxide & 3.02 & 3.22 \\
\hline \multicolumn{2}{|c|}{} & $\mathrm{g} / \mathrm{mL}$ \\
\hline \multicolumn{2}{|c|}{$\mathrm{g} / \mathrm{mL}$} & 1.37 \\
\hline Density & 1.35 & \\
\hline
\end{tabular}


SRNL-STI-2011-00375

Revision 0

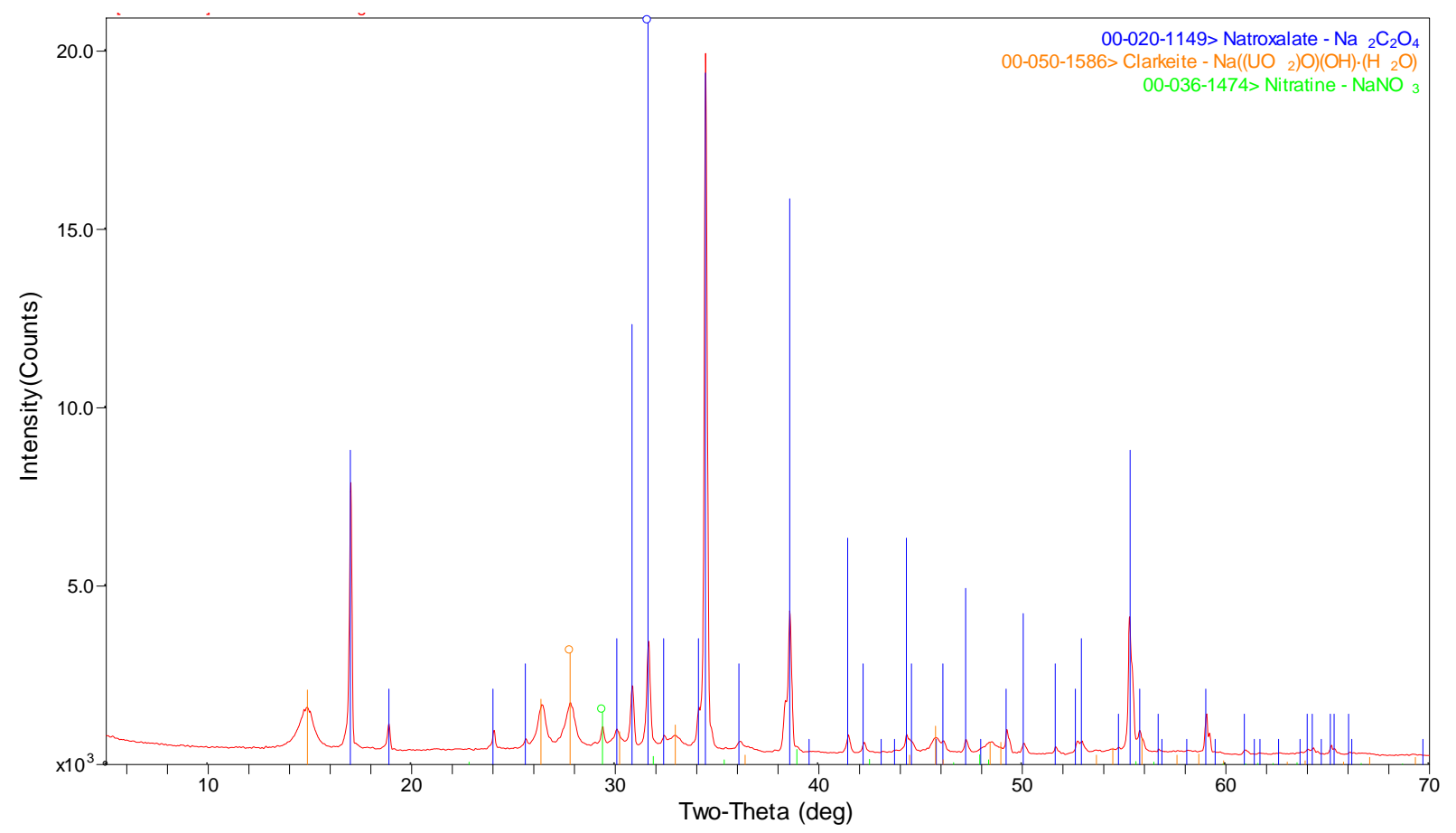

Figure 3-1. XRD analysis results for unwashed solids isolated from Tank 26F Sample FTF-26-10-57.

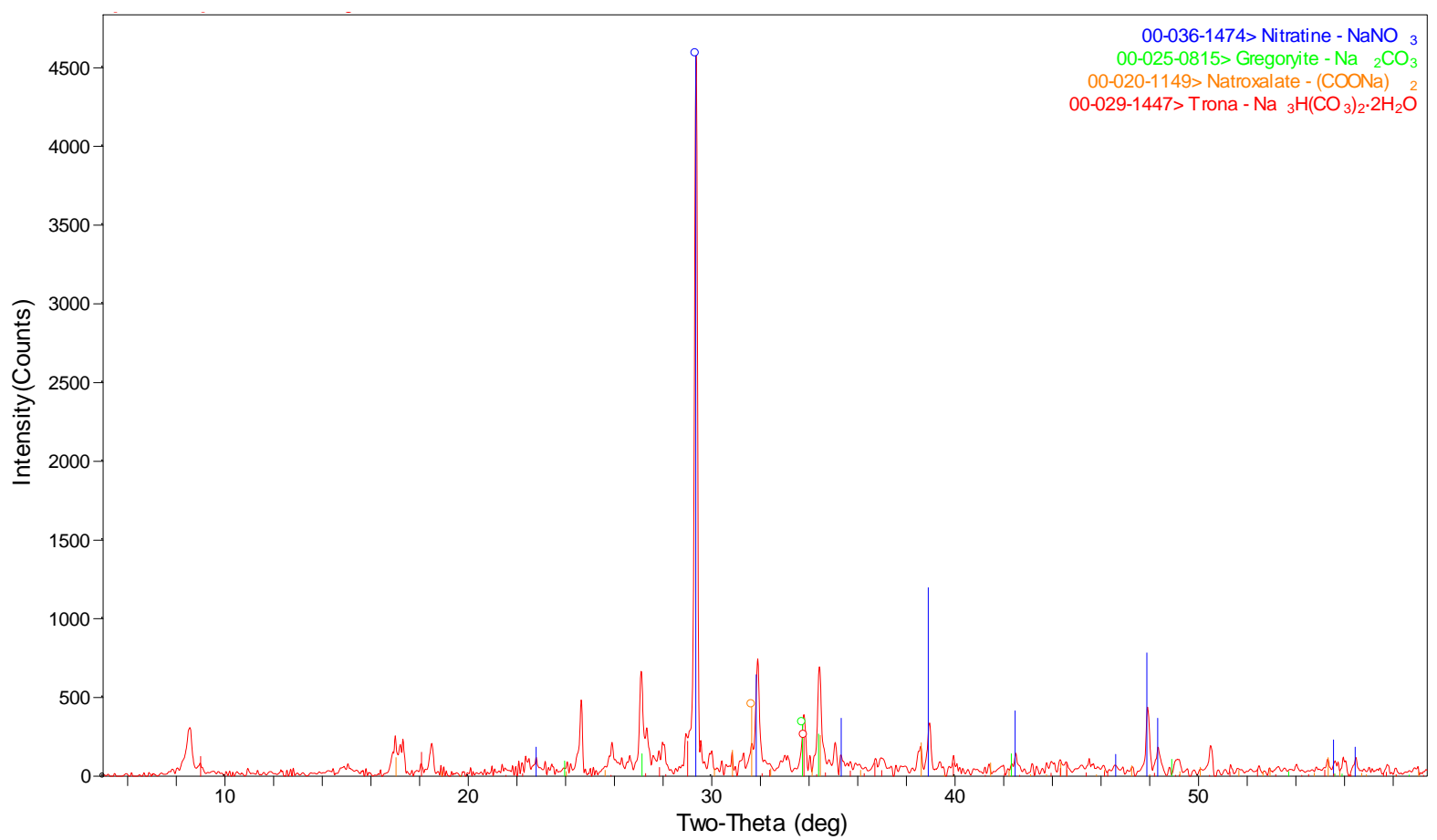

Figure 3-2. XRD analysis results for unwashed Eductor Pump solids. 
SRNL-STI-2011-00375

Revision 0

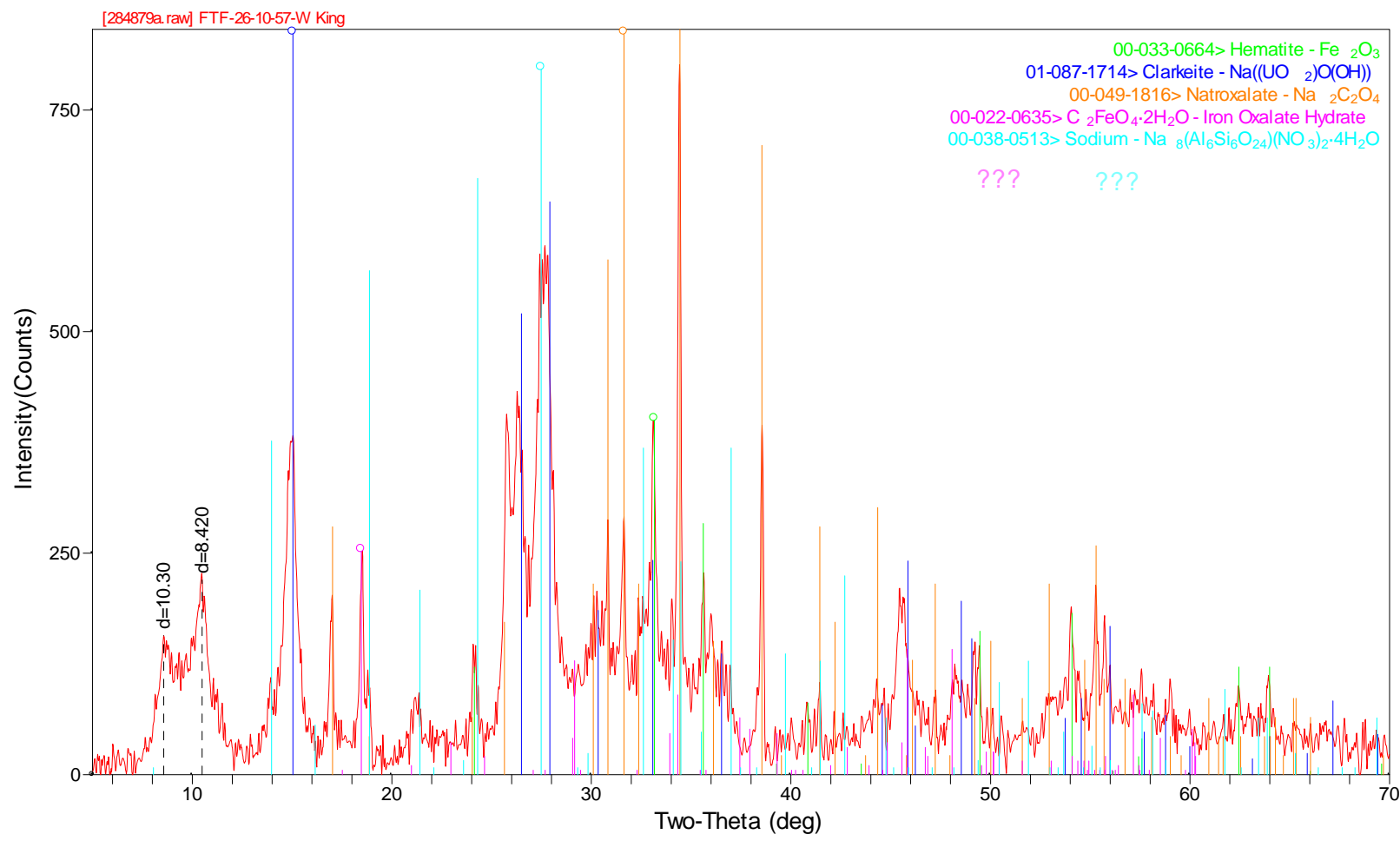

Figure 3-3. XRD analysis results for water-washed solids isolated from Tank 26F Sample FTF-26-10-57.

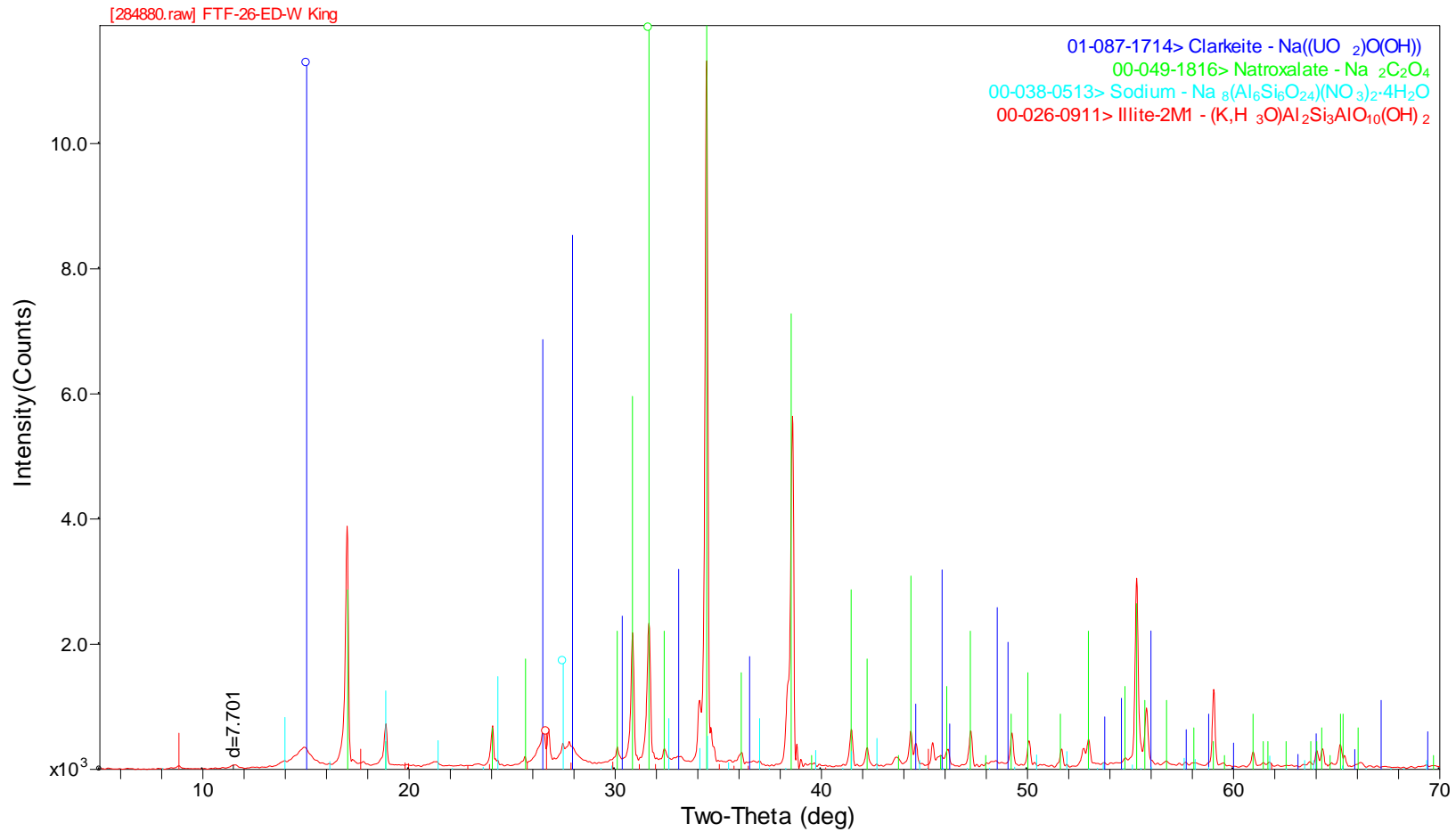

Figure 3-4. XRD analysis results for water-washed Eductor Pump solids. 


\subsection{Conclusions}

Based on the experimental and modeling results, it is believed that various types of solid phases may be precipitating within the $2 \mathrm{~F}$ evaporator system and contributing to the operational problems. The results indicate that oxalate salts, in particular, are very insoluble in the concentrated sodium stream currently fed to the evaporator and that oxalate precipitation occurs in the system. Solids observed in the Tank 26F evaporator feed samples are believed to have formed during the three month interim storage period in the SRNL shielded cells prior to sample inspection and analysis.

\subsection{Recommendations}

Given the low solubility of sodium oxalate salts in high sodium feed solutions, it is recommended that streams known to contain higher oxalate levels be processed under less concentrated conditions. However, thermodynamic modeling indicates that oxalate precipitation will likely be problematic even in more dilute solutions. The presence of various other solid phases within the $2 \mathrm{~F}$ evaporator system also indicates that operation under less concentrated conditions may be preferred to avoid precipitation and plugging of system components even in the absence of oxalate salts. 


\subsection{References}

1. “2F Evaporator Pluggage Issues”, HLE-TTR-2011-002, Rev. 0, January, 2011.

2. King, W. D. "Task Technical and Quality Assurance Plan for Sample Characterization and Testing to Support 2F Evaporator Operations" SRNL-RP-2011-00272, Rev. 0, March 2011. 


\section{Distribution:}
A. B. Barnes, 999-W
C. E. Duffey, 704-61H
D. A. Crowley, 773-43A
A. W. Wiggins, 704-60H
A. P. Fellinger, 773-41A
D. J. Martin
S. D. Fink, 773-A
E. J. Freed
B. J. Giddings, 786-5A
C. C. Herman, 999-W
S. L. Marra, 773-A
A. M. Murray, 773-A
F. M. Pennebaker, 773-42A
W. D. King, 773-42A
M. S. Hay, 773-42A
A. L. Washington, 773-42A
C. J. Martino, 773-42A
C. J. Coleman, 773-A
W. R. Wilmarth, 773-A
P. R. Jackson, DOE-SR, 703-46A
K. H. Subramanian, 766-H 